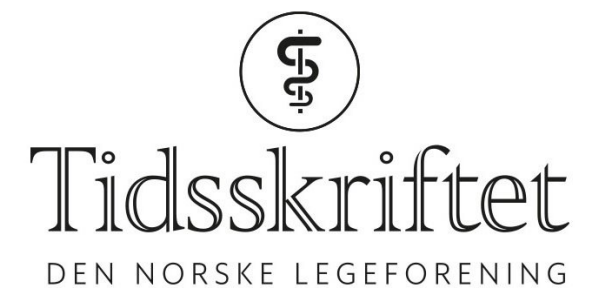

DEN NORSKE LEGEFORENING

\title{
Kommentar til «Den kvasse samtalen»
}

KOMMENTAR

JØRAN HJELMESATH

E-post: joran.hjelmeseth@siv.no

Jøran Hjelmesæth er spesialist i indremedisin og nyresykdommer, senterleder ved Senter for sykelig overvekt i Helse Sør-Øst, Sykehuset i Vestfold og professor ved Universitetet i Oslo.

JENS K. HERTEL

Ingen av forfatterne har oppgitt noen interessekonflikter.

Vi takker Odd Martin Vallersnes for en viktig og godt poengtert leder om språkvalg ved disputaser i Norge (1). Ingen er vel uenig i at det er avhandlingens vitenskapelige kvalitet som skal være hovedtemaet for diskusjonen mellom doktorand og opponent, men vi har reagert med undring på at medisinsk fakultet ved Universitet i Oslo har bestemt at disputasen uten unntak skal foregå på avhandlingsspråket (2). En uheldig konsekvens av dette er at de fleste norske kandidater og opponenter, også skandinaviske, som ikke har engelsk som sitt førstespråk, tvinges til å kommunisere gjennom «bad English» som utvilsomt svekker kvaliteten på den vitenskapelige diskusjonen, og som i verste fall kan utvikle seg til en tragikomisk "god dag mann økseskaft»-samtale hvor både kandidat og opponent er like språkforvirret, en seanse som ikke er en disputas verdig.

Et godt argument fra Ivar Gladhaug (3) for å holde disputasen på engelsk er «at ph.d.kandidatar skal kunna driva forsking på høgt internasjonalt nivå, formidla forskinga i anerkjente internasjonale kanalar og kunna delta i debattar i fagområdet i internasjonale forum. I desse fora er språket engelsk og det er derfor viktig for fakultetet at kandidaten blir testa i dette ved doktorgradsprøven.» (3). Det er vel og bra at kandidater får trening i engelsk slik at de aktivt kan delta i internasjonale fora, men doktorgradsprøven er ingen språktest, og bør ikke være en arena hvor språket legger begrensing på samtalens faglige nivå. Vår egen erfaring med flere utenlandske samarbeidspartnere er at dårlig muntlig engelsk er en felles utfordring, men at dette korrigeres gjennom skriftlig kommunikasjon og kvalitetssikring. I tillegg vil unge forskere ha et betydelig bedre grunnengelsk enn vi som har vært med noen år. Problemet med dårlig engelsk er heldigvis mindre uttalt i artikler og avhandling, siden skriftlig engelsk kan kvalitetssikres gjennom samarbeid med medforfattere, profesjonell språkvask, og kommunikasjon med tidsskriftene.

Alle doktorander som har disputert ved Senter for sykelig overvekt i Helse Sør- Øst ved Sykehuset i Vestfold de siste årene med skandinavisk utenlandsk opponent har valgt norsk (skandinavisk) som disputasspråk, og det har fungert meget tilfredsstillende. At skandinaviske opponenter og norske ph.d.-kandidater skal tvinges til en vitenskapelig diskusjon på «bad English» vil kunne redusere verdien av denne viktige begivenheten.

Vi støtter derfor forfatteren i at «Det medisinske fakultet ved Universitetet i Oslo bør ta sin 
del av ansvaret ved å la doktorander og opponenter diskutere på norsk/skandinavisk når dette er språket de i fellesskap behersker best.»

\section{LITTERATUR:}

1. Vallersnes OM. Den kvasse samtalen. Tidsskr Nor Legeforen 2020;140. doi:10.4045/tidsskr.20.0076. [CrossRef]

2. Universitetet i Oslo. Det medisinske fakultet. Om doktorgradsprøve.

https://www.med.uio.no/forskning/phd/avhandling-bedommelse/proveforelesning-disputas/doktorgr adsprove/ Lest 6.3.2020.

3. Toft M. MED innskjerpar reglane: Ikkje rom for anna talemål enn avhandlingsspråket på disputasen. Uniforum 7.6.2019.

https://www.uniforum.uio.no/nyheter/2019/o6/med-innskjerpar-reglane-ikkje-rom-for-anna-talemal.h tml Lest 6.3.2020.

Publisert:30. mars 2020. Tidsskr Nor Legeforen. DOI:10.4045/tidsskr.20.0199

(C) Tidsskrift for Den norske legeforening 2020. Lastet ned fra tidsskriftet.no 